\title{
NEWSPAPER FRAMING OF THE ACTIVITIES OF THE ECONOMIC AND FINANCIAL CRIMES COMMISSION UNDER PRESIDENT MUHAMMADUBUHARI'S ADMINISTRATION
}

Ikusemiju Ayokunle Oluwadamilare $^{1^{*}}$, Anthony Ekwueme ${ }^{2}$

${ }^{1 * 2}$ Department of Mass Communication, University of Nigeria, Nsukka, Nigeria.

Email: "ejinnachinedu@yahoo.com

Article History: Received on $12^{\text {th }}$ April 2020, Revised on $18^{\text {th }}$ August 2020, Published on $1^{\text {st }}$ October 2020

\begin{abstract}
Objectives of the Study: The purpose of this study was to examine newspaper framing of the activities of the EFCC under President Buhari, using four purposively selected newspapers. In doing this, the researchers focused on the prevalence of frames, most prominent frames, and interpretations they gave to the activities of EFCC.

Methodology: Content analysis and critical discourse analysis were adopted as the research methods. By means of the constructed week sampling technique, 288 editions of the selected newspapers years were studied.

Results: It was found that six (6) frames constituted 75\% frame prevalence rate, while two (2) frames constituted 15\% non-prevalence rate. The corruption-combating/criminalisation frame was the most prominent. Interpretation of the reports revealed that some newspapers presented EFCC as victimisers, while some appraised its activities at mitigating graft in Nigeria.
\end{abstract}

Application/implications: The implication of these results is that journalists need to improve in their framing anticorruption efforts as part of their social responsibility to the Nigerian society.

Originality/ Novelty: This study has contributed to our understanding of the role of the media in promoting good governance and accountability in a developing country like Nigeria.

Keywords: Administration, Buhari, Corruption, Economic and Financial Crimes, Framing, Nigerian Newspapers.

\section{INTRODUCTION}

Economic and financial crimes are acts perpetrated by the person(s) for financial gain. Notable among such crimes are money laundering, fraud, levy skirting, human trading, cyberstalking, and others (Mailafia, 2017). Economic and financial crimes have been limiting Nigeria's development since independence but in the late 1980 Nigerian government proposed to establish an agency solely to investigate economic and financial crimes, owing to the severe negative consequence they conferred on the nation's image. Moreover, the Financial Task Force on Money Laundering (FATF) at that time listed the country as uncooperative in global struggles to combat corruption, and Nigeria was required to implement Recommendation 26 of the FATF's then 49 recommendations that requires the establishment of a Financial Intelligence Unit (Waziri, 2011).

Owing to this, in 2002, the then President of Nigeria, Chief Olusegun Obasanjo, established the Economic and Financial Crimes Commission (EFCC), as the government agency that investigates and prosecutes economic and financial crimes (EFC). Since its attainment of a legal status (EFCC Establishment Act 2004, as amended), it has been responsible for prosecuting and securing the conviction of several high-profile financially corrupt persons, ranging from government officials, the political class, and judicial officers to financial industries. Barely three years after its establishment, EFCC had investigated 31 out of Nigeria's 36 State Governors for pecuniary crime (Human Rights Watch, 2011). It also prosecuted and convicted TafaBalogun, Nigeria's former Police Chief; prosecuted ex-Governor DiepreyeAlamiesigha of Bayelsa State; and several bank chief executives, public officers, and top civil servants like former Chairman of the Nigeria Pension Commission, Abdul RasheedMaina, former Director-General and politicians like James Ibori, Asiwaju Bola Ahmed Tinubu, DimejiBankole, Patricia Eteh, among others. Thereafter, the Commission was perhaps in-effectual as not much was heard about it.

However, on the assumption of office in 2015, President MuhammaduBuhari began his crusade against economic and financial crimes by giving the needed administrative support to the EFCC. The anti-graft agency was revamped and between November 2015 and March 2019, recovered N794B; \$261M (about 77.8 billion naira); £1,115, 930.47; 8,168,871.13Euros; 86,500CFA; secured 703 convictions (103 persons in 2015, 194 persons in 2016, 189 persons in 2017 and 217 persons in 2018). It also secured the loss of the following properties to the Nigeria Government: 407 mansions of which 126 are permanently seized, 9 filling stations, 98 plots of land (56 under temporary loss while 42 have been lost finally), and 259 automobiles (35 under interim forfeiture and 224 finally forfeited) (Magu, 2018). Similarly, between 2018 and 2019, the EFCC investigated prominent Nigerians like LawalJafaru Isa, OlisaMetuh, EmekaMba, JideOmokore, Tom Ikimi, Air Vice Marshal R.A. Ojuawo, Ricky Tarfa, BalaNgilari, Patrick Akpobolokemi, SamboDasuki, MusiliuObanikoro, Ayo Fayose, Alhaji Abdullahi Dikko, and many others (The Daily Trust 05/03/2018). 
The ways in which the media frame the activities of the EFCC is important because it will influence public opinion. Gever (2018), Gever, et al., (2019) are also of the view that media framing in general essential roles in influencing how people feel about issues. This, therefore, implies that newspaper framing of the activities of the EFCC is essential because it will play a role concerning how people feel about the agency. It will also go a long way in highlighting the contribution of the media in promoting accountability in governance. Therefore, the objective of this study was to determine how Nigerian newspapers frame the activities of the Economic and Financial Crimes Commission under the administration of President Muhammadu Buhari.

\section{Objectives of the Study}

This study's broad goal was to examine Nigerian newspapers framing of the activities of EFCC under President MuhammaduBuhari's administration. The precise objectives were to:

1. Determine the prevalent frames used by Nigerian newspapers in reporting activities of the Economic and Financial Crimes Commission (EFCC) under President Muhammadu Buhari;

2. Ascertain the most prominent frame utilised by selected Nigerian newspapers in reporting activities of EFCC; and

3. Determine the interpretation Nigerian newspapers gave to the activities of EFCC under President Buhari.

\section{LITERATURE REVIEW}

Having understood the threats, monetary crime poses to Nigeria's advancement, upon resuming office in 2015, President MuhammaduBuhari re-energized the anti-graft agency, to investigate, arrest, and prosecute corrupt persons. The following are some of such cases being investigated and put on trial by the EFCC under President MuhammaduBuhari:

\section{i. The $\$ 2.1 B$ Arms Deal (Dasukigate)}

The Nigeria government had towards the twilight of the former President Jonathan's administration approved the procurement of arms worth $\$ 2.1 \mathrm{~b}$ (N10 billion) to enable Nigeria military sufficiently counter and suppress the Boko Haram menace that was seriously ravaging the lives of people in North-East - Nigeria and tactically taking over some of the territorial grounds of the Nigeria government. These arms were to be purchased by the former National Security Adviser to former President Jonathan, Col. SamboDasuki (rtd.), however, they were never purchased but the money diverted for election and other personal/party purposes (Venturesafrica, $n . d$ ).

Dasuki has since been arraigned before the Court by the EFCC, while some of his accomplices who could not go by the way of a plea bargain to refund the arms deal money have now been arraigned before the Court.

It is worthy to note that the Arms Procurement Investigative Committee's report revealed that the sum of N643.8 billion and $\$ 2.2$ billion not captured in the year's budget was also spent under this deal in the watch of former President Jonathan. The Committee also discovered about 53 failed contracts amounting to $\$ 2,378,939,066.22$ and N13,729,342,329.87out of 513 contracts awarded.

\section{ii. Financial scandal to the tune of N33b at NEMA}

The House of Representatives in November 2017 indicted the Director-General, National Emergency Management Agency (NEMA), Mustapha Maihaja, and the body for mismanaging the sum of N5.8b allocated to the North/Eastern part of Nigeria. The lower chamber further argued that the procedure for release of the fund to NEMA as emergency food intervention in the North East flouts Section 80(4) of the 1999 Constitution, as amended. Meanwhile, Vice PresidentYemiOsinbajo had authorized the disbursement of the fund while he was Acting President during one of the numerous visits of President Buhari abroad.

Investigations conducted by the Lawmakers further revealed that the release of N5.8b, N3.1b food intervention fund to the North East in 2017, 6,779 metric tonnes of rice offered by China to Internally Displaced Persons in the North East and N800m demurrage paid for the rice did not get to Internally Displaced Persons in the North East, therefore, concluded that Nigeria Government lost the sum N33b as a result of the mismanagement by the Director-General of NEMA.

\section{iii. Fraud at the Nigerian Liquefied Natural Gas (NLNG)}

During the period of fuel scarcity in late 2017 and early 2018, the federal government took some drastic steps to stem down the pains of the period on Nigerians. Then, the government was obviously caught illegally paying subsidy without authorization or budgetary provision. In October 2017, the Nigerian National Petroleum Corporation (NNPC) was captured to have unlawfully spent N378b from the Nigerian Liquefied Natural Gas (NLNG) dividends on clandestinely finance petrol subsidy payment for its supply and distribution into the country, when the money belongs to all tiers of government.

This fraud was discovered by the National Assembly, and it queried that the government officials involved refused to consult with other required bodies before spending the fund. It thus described the action (payment of subsidy) as illicit and directed an inquiry into the matter and officials involved. 


\section{iv. Ayo Fayose and the Dasuki Gate}

In the twilight of the tenure of the former Governor of Ekiti State, Peter Ayodele Fayose, EFCC invited him over his connection to the Arms deal, as confessed by Musiliu Obanikoro, the former Minister of Defence (State). On the same day his second term tenure ended, $16^{\text {th }}$ October 2018, Mr. Ayo Fayose reported himself EFCC in Abuja. This was widely reported by several media within and outside Nigeria. The anti-graft agency had alleged that he received N1.3b from SamboDasukiin the twilight of the Ekiti State Governorship election in 2014. The agency upon interrogating Ayo Fayose, after some days in detention, charged him to court for conspiracy and money laundering. Though the case is still pending at the Court of Law, he has since been granted bail (Pulse, 2018).

v. Incarceration of Joshua Dariye, former Governor of Plateau State, and Jolly Nyame, former Governor of Taraba State

On $13^{\text {th }}$ June, 2018, Justice AdebukolaBanjokocondemned former Governor Dariye(even while he was a serving Senator) to fourteen (14) years prison term for criminal breach of trust and diverting N1.62b State Ecological Funds during his tenure as Governor of Plateau State from 1999 to 2007.

On $30^{\text {th }}$ May, 2018, the same Judge again condemned former Governor of Taraba State, Jolly Nyame to fourteen (14) years imprisonment without fine, for receiving inducing, misappropriating public fund, and criminal breach of trust.

\section{Empirical literature}

Framing research in the area of economic and financial crimes has so far focused on framing and corruption, anticorruption, governance, terrorism, and politics. Therefore, this study focused attention on previous literatures on the framing of anti-corruption and other issues framing research has established prominence. They are discussed as follows:

Olijo (2017) carried out a study on an assessment of newspaper framing of the anti-corruption war of President Muhammadu Buhari, with an explicit interest in framing text format, prominence, and depth of coverage. The Punch and Daily Trust between June $1^{\text {st }} 2015$ and January $30^{\text {th }} 2016$ (7 months and 28 weeks) were sampled, using content analysis. Findings from the study indicated that most (67\%) of the newspaper frames were neutral on Buhari's' anti-corruption war. Also, most $(39.3 \%)$ of the stories on Buhari's anti-corruption war within the study duration were straight news. Only $14.4 \%$ of the stories were found to be an investigative report, while most $(33.8 \%)$ of the anti-corruption stories occupied quarter pages.

Salaudeen, et al., (2018) also carried out an investigation on Framing of the Anti-Graft War in selected Nigerian Newspapers, to content analyse newspaper framing of Nigeria's anti-graft war by Guardian and Punch newspapers between June 2015 and May 2016 (1 year). The study adopted systematic random sampling to choose 184 editions for the investigation and it discovered 452 corruption issues selected through purposive sampling technique and analysed the same in the study.

Findings indicated that even though there were numerous corruption-related stories in the selected editions, prominence was not given to corruption stories and the newspapers did not carry out interpretative reporting on the issues. It then suggested among others, that prominence, investigative, and interpretative writing should be devoted to anti-graft issues by Nigerian media in order to set and promote policy agenda.

Onyebuchi and Obayi (2019) did a study to ascertain the extent to which media have been able to cover the rebranding Nigeria Company. Using content analysis, the researchers analysed three newspapers (This Day, Daily Sun, and The Guardian) editions published within a year (January to December, 2009). Findings showed that the rebranding Nigeria campaign was under-reported in the newspapers.

Okoro and Odoemelam (2013) conducted a study to identify the frame patterns embraced by Nigerian tabloids in covering war against Boko Haram. Content analysis was adopted for the study and the researchers utilized simple random sampling to select 144 issues of the dailies published between January 2012 and December 2012. Findings indicated that the policy response frame was the leading frame and this was uniform in all the newspapers investigated except Daily Sun that ethnic and religious frames were dominant.

Ngwu, et al., (2015) investigated the news frame of the April 14, 2014 school girls' abduction and how such frames influenced the audience. Content analysis and survey methods were utilised to know the frames in addition to their impact on the audience. Political, hopelessness, rescue efforts, conspiracy, religious, economic, and ethnic frames were identified as frame categories in the study, while the hopeless frame was the dominant frame. Thus, making readers discard any rescue operation introduced to save the school girls.

Egbunike (2015) media framing of political protests in Nigeria and found that newspapers were more proactive in framing enthusiasm, belief, and scenario of the protest. Onifade (2015) studied how Nigerian newspaper columnists reiterate and re-articulate politics and history-based events in their analysis of the presidential election in March 2015.

Findings showed that the political and economic class in the Nigeria society used their own control to sway the writings of the columnists in their publications, while the specialised writers also use impulsive ideas like race and religion in writings to influence the audience and cascade individuals to take partisan judgements that errand political elitists. See 
also Anyadike (2015); Abubakre (2017); Udende and Chile (2017) Chime-Nganya, et al, (2017); Adekunle (2017); Ukonu and Ajaero (2017); Amenaghawon (2017); Abdulbaqi and Ariemu (2017); Badiru and Sunmonu (2018); Adekola and Lamond (2018); Nwabueze and Ezebuenyi (2019); Nwammuo et al., (2019) for more on media framing of issues of public interest. It is essential to add here that so far, media framing of the activities of the Economic and Financial Crimes Commission under President Buhari has not received attention in literature. This is despite the fact that $\mathrm{Mr}$ Buhari made fighting a cardinal part of his administration. This study attempted to fill this gap.

\section{Theoretical Framework}

Upon critical review of related theories, the theory that was found most appropriate for this investigation is the framing theory. McQuail (2005) explained that framing theory identifies phenomena, discusses acts about it, take a position, and recommends solutions. It explained that mass media regularly adopt the use of some specific words or language, make reference to some contextual sources, select certain movies or pictorial representations, and refer to a particular case study in conveying its messages to its audience, thus, tinting the mind-set of the audience towards a preconceived thought. The theory has several paradigms as argued by Scheufele (1999) cited in McQuail (2005), where it describes framing effect as an interrelated process that involves three actors - the source, the media, and the audience. Accordingly, it explains that, one; there is the consistent use of media frames by media workers, particularly newspaper writers in the course of writing news stories or other pieces for publication on a daily basis, thereby dealing with certain sources consistently and applying news judgment before disseminating the message to the public. Two, there exist transfer of "framed" news report (for instance, the pessimistic outlook of a Nigerian public office holder as corrupt) to the audience. Three, the members of the public constituting the audience accept the frames from the media, with apparent reflection in their attitudes, perception, behavior, comment, belief, and disposition to the issue. See also Fair $e t$ al., (1996). Simply put, in framing, the focal point is not on the number of stories but the angle used. Therefore, the researchers regarded the framing theory as important to assist the researcher in understanding how the media highlight the activities of EFCC under the administration of Muhammadu Buhari.

\section{METHODOLOGY}

The study adopted content analysis and critical discourse analysis as research methods. This is because the study involved examination of the manifest contents of selected Nigerian newspapers. Scholars (Ale, 2020; Kari 2020; Melugbo et al., 2020 Odii 2020; Ogbonne, 2020) are of the view that a research design should be such that aid researchers to accomplish their study objectives. Accordingly, content analysis was adopted as the main method, while critical discourse analysis was adopted to gain insights into the text from the newspapers. The population of the study comprised all newspapers published and circulated in Nigeria during the time of this study (November 1, 2015 to October 31, 2018), while the researcher purposively selected four newspapers namely, Daily Trust, Daily Sun, Leadership and Punch newspapers out of this population for the study. A sample size of 288 editions (72 editions per newspaper) out of 4380 issues of the four selected newspapers were examined. Each of the selected newspaper is widely circulated and read across Nigeria; has the capacity for deeper reportage/analysis of events/issues.

The study adopted a constructed week sampling technique. This is based on the opinion of Obayi, et al., (2016) that the use of composite week sampling technique is the most appropriate sampling technique for content analysis.

Constructed on the above sample size, this study investigated 288 editions (72 editions from each newspaper) of the four selected newspapers (Daily Trust, Daily Sun, Leadership, and Punch newspapers) for the period of three years (36 months or 156 weeks) of November 2015 to October 2018. Using the above technique, the researcher constructed the days of the week in a month to have just twelve months in a year and thereafter picked two editions from each basket to make up 24 editions for each year of the selected newspapers; and the instrument of data collection used for this study was the code sheet. It was used to gather, sort, record, and code data in the editions of the newspaper investigated. The instrument for data collection was the code sheet that was developed for the study. The inter-coder reliability was using percentage agreement, and this yielded 75 prevalent frames, 77 for the prominent frame, and 88 interpretation. This means that the instrument was reliable. The following frames were measured in the study:

Table 1: Showing Categories of Frames for the Study

\begin{tabular}{lll}
\hline S/N & FRAMES & INDICATORS OF CODING \\
\hline 1. & Mockery & $\begin{array}{l}\text { Frames that tend to ridicule efforts/actions of the EFCC or federal } \\
\text { government to mitigate economic and financial crimes }\end{array}$ \\
\hline 2. & Political influence & $\begin{array}{l}\text { Reports that cover the government's activeness or otherwise, through its } \\
\text { policies, on activities of the EFCC. }\end{array}$ \\
\hline 3. & $\begin{array}{l}\text { Witch-hunting/ } \\
\text { Victimization }\end{array}$ & $\begin{array}{l}\text { This has to do with words that suggest that President Buhari' santi- } \\
\text { corruption war is biased towards oppressing political opponents. That is, the } \\
\text { fight against economic and financial crimes is meant to score political points } \\
\text { in favour of the Buhari led administration. }\end{array}$ \\
\hline 4. & Neutral & $\begin{array}{l}\text { This has to do with use of words simply to inform or educate the public } \\
\text { about activities of EFCC or the anti-graft war in Nigeria, without any form }\end{array}$ \\
\hline
\end{tabular}




\begin{tabular}{|c|c|c|}
\hline & & of subjective opinion/input. \\
\hline 5. & $\begin{array}{l}\text { Corruption-combating/ } \\
\text { Criminalization }\end{array}$ & $\begin{array}{l}\text { Frames or words that identify (suspected) perpetrators of economic and } \\
\text { financial crimes as well as the arrest, interrogation, remand, prosecution, and } \\
\text { conviction of economic and financial crimes suspect. }\end{array}$ \\
\hline 6. & Recommendations & $\begin{array}{l}\text { Frames that suggested solutions to the problem of economic and financial } \\
\text { crimes or how EFCC can execute its objectives excellently }\end{array}$ \\
\hline 7. & $\begin{array}{l}\text { Effect/Economic } \\
\text { consequence }\end{array}$ & $\begin{array}{l}\text { Frames that mention financial risk and loss indicated by economic and } \\
\text { financial crimes }\end{array}$ \\
\hline 8. & Attribution of responsibility & $\begin{array}{l}\text { Frames that identify the person/body causing corruption and which person } \\
\text { has the potential of controlling it. }\end{array}$ \\
\hline
\end{tabular}

\section{Data Presentation/Analysis/ Discussion of Findings}

\section{Research Question One:}

What were the frames used by the Nigerian newspapers in reporting activities of the Economic and Financial Crimes Commission (EFCC) under President Buhari?

Table 2: Showing prevalence rate of frames used by Nigerian newspapers in framing reports on EFCC

\begin{tabular}{|c|c|c|c|c|c|c|c|c|c|}
\hline $\begin{array}{c}\text { Newspa } \\
\text { per }\end{array}$ & $\begin{array}{l}\text { Mocker } \\
\text { y }\end{array}$ & $\begin{array}{l}\text { Pol } \\
\text { influen } \\
\text { ce }\end{array}$ & $\begin{array}{l}\text { Witch- } \\
\text { hunting/vi } \\
\text { ctim }\end{array}$ & Neu & $\begin{array}{l}\text { Corrupt } \\
\text { ion- } \\
\text { combati } \\
\text { ng/ crim }\end{array}$ & $\begin{array}{l}\text { Recommend } \\
\text { ation }\end{array}$ & $\begin{array}{l}\text { Effect/Ec } \\
\text { on } \\
\text { Consequ } \\
\text { ence }\end{array}$ & $\begin{array}{l}\text { Attrib } \\
\text { of resp }\end{array}$ & Total \\
\hline $\begin{array}{l}\text { Daily } \\
\text { Trust }\end{array}$ & $\begin{array}{l}10(11.3 \\
6 \%)\end{array}$ & $\begin{array}{l}2(12.5 \\
\%)\end{array}$ & $3(7.32 \%)$ & $\begin{array}{l}6(8.11 \% \\
)^{6}\end{array}$ & $8(6.84 \%)$ & $8(11.77 \%)$ & 0() & $\begin{array}{l}7(22.58 \\
\%)\end{array}$ & $\begin{array}{l}44(10.05 \\
\%)\end{array}$ \\
\hline $\begin{array}{l}\text { Leaders } \\
\text { hip }\end{array}$ & $\begin{array}{l}7(7.96 \% \\
\text { - }\end{array}$ & $\begin{array}{l}6(37.5 \\
\%) \\
\end{array}$ & $\begin{array}{l}10(24.39 \% \\
)\end{array}$ & $\begin{array}{l}15(20.2 \\
7 \%)\end{array}$ & $\begin{array}{l}19(16.24 \\
\%)\end{array}$ & $5(7.35 \%)$ & $\begin{array}{l}1(33.33 \% \\
)\end{array}$ & 0() & $\begin{array}{l}63(14.38 \\
\%)\end{array}$ \\
\hline $\begin{array}{l}\text { Daily } \\
\text { Sun }\end{array}$ & $\begin{array}{l}38(43.1 \\
8 \%)\end{array}$ & $\begin{array}{l}3(18.75 \\
\%)\end{array}$ & $11(26.83 \%$ & $\begin{array}{l}34(45.9 \\
5 \%)\end{array}$ & $\begin{array}{l}36(30.77 \\
\%)\end{array}$ & $21(30.88 \%)$ & $\begin{array}{l}1(33.33 \% \\
)\end{array}$ & $\begin{array}{l}4(12.9 \% \\
\text { ) }\end{array}$ & $\begin{array}{l}148(33.7 \\
9 \%)\end{array}$ \\
\hline Punch & $\begin{array}{l}33(37.5 \\
\%)\end{array}$ & $\begin{array}{l}5(31.25 \\
\%)\end{array}$ & $\begin{array}{l}17(41.46 \% \\
)\end{array}$ & $\begin{array}{l}19(25.6 \\
8 \%)\end{array}$ & $\begin{array}{l}54(46.15 \\
\%)\end{array}$ & $34(50 \%)$ & $\begin{array}{l}1(33.33 \% \\
)\end{array}$ & $\begin{array}{l}20(64.5 \\
2 \%)\end{array}$ & $\begin{array}{l}183(41.7 \\
8 \%)\end{array}$ \\
\hline Total & $\begin{array}{l}88(100 \\
\%)\end{array}$ & $\begin{array}{l}16(100 \\
\%)\end{array}$ & $41(100 \%)$ & $\begin{array}{l}74(100 \\
\%)\end{array}$ & $\begin{array}{l}117(100 \\
\%)\end{array}$ & $68(100 \%)$ & $3(100 \%)$ & $\begin{array}{l}31(100 \\
\%)\end{array}$ & $\begin{array}{l}438(100 \\
\%)\end{array}$ \\
\hline
\end{tabular}

Source: Field Study, 2019

Table 2 above showed that 8 frame categories were used to determine the prevalence of frames used by newspapers in reporting activities of the Economic and Financial Crimes Commission under President MuhammaduBuhari. It illustrated that out of the 8 frame categories, 6 frames representing $75 \%$ were prevalent. They are the mockery frame, witch-hunting/victimization frame, neutral frame, political influence frame, corruption-combating/criminalization frame, and recommendation frame. The remaining two (2) frames representing $15 \%$ were not prevalent because not all the newspapers utilized them in reporting the activities of EFCC. They are: effects/economic consequence frame and attribution of responsibility frame. It can also be seen from the table above that the Daily Trust newspaper did not use effects/economic consequence frame. In contrast, the Leadership newspaper did not use attribution of responsibility frame. This finding also affirmed the findings of Ngwu and Chiaha (2015), Udende and Chile (2017), and Adekunle (2017), specifically in the area of frames manifestation.

\section{Research Question Two}

What was the most prominent frame used by the selected Nigerian newspapers in framing the activities of EFCC?

Table 3: Showing the most prominent frame used by Nigerian newspapers in framing reports on EFCC

\begin{tabular}{llllll}
\hline Frames & Daily Sun & Leadership & Daily Trust & Punch & Total \\
\hline Mockery & $38(25.68 \%)$ & $7(11.11 \%)$ & $10(22.73 \%)$ & $33(18.03 \%)$ & $88(20.09 \%)$ \\
\hline Political influence & $3(2.03 \%)$ & $6(9.53 \%)$ & $2(4.55 \%)$ & $5(2.73 \%)$ & $16(3.65 \%)$ \\
\hline $\begin{array}{l}\text { Witch- } \\
\text { hunting/victimisation }\end{array}$ & $11(7.43 \%)$ & $10(15.87 \%)$ & $3(6.82 \%)$ & $17(9.29 \%)$ & $41(9.36 \%)$ \\
\hline Neutral & $34(22.97 \%)$ & $15(23.81 \%)$ & $6(13.64 \%)$ & $19(10.38 \%)$ & $74(16.9 \%)$ \\
\hline $\begin{array}{l}\text { Corruption- } \\
\text { combating/criminalization }\end{array}$ & $36(24.32 \%)$ & $19(30.16 \%)$ & $8(18.18 \%)$ & $54(29.51 \%)$ & $117(26.71 \%)$ \\
\hline Recommendation & $21(14.19 \%)$ & $5(7.94 \%)$ & $8(18.18 \%)$ & $34(18.58 \%)$ & $68(15.53 \%)$ \\
\hline $\begin{array}{l}\text { Effects/economic } \\
\text { consequence }\end{array}$ & $1(0.68 \%)$ & $1(1.59 \%)$ & 0() & $1(0.55 \%)$ & $3(0.69 \%)$ \\
\hline
\end{tabular}




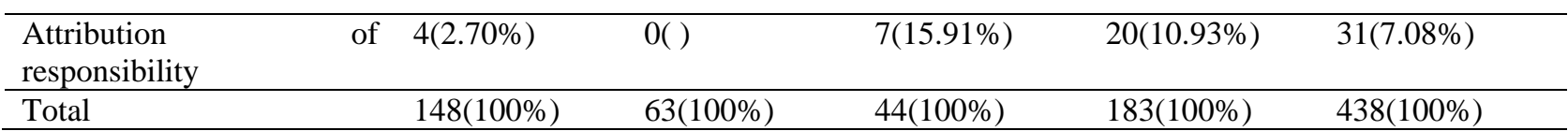

Source: Field study, 2019

Table 3 above showed that in the four newspapers (Daily Trust, Daily Sun, Punch, and Leadership) selected for this study, frames appeared four hundred and thirty-eight (438) times in the newspaper's reportage of activities of EFCC under President Buhari. It can be deduced from the table that the corruption-combating/criminalization frame (26.71\%) was the most prominent frame used by the newspapers in reporting activities of EFCC under President Buhari. The implication of this is that under President Muhammad Buhari's administration, Nigerian newspapers presented reports of EFCC in the light of its efforts at combating corruption - arresting, investigating, and prosecuting graft suspects. The mockery frame $(20.09 \%)$ came second, while the last frame was the effects/economic consequence frame $(0.69 \%)$. This result is similar to that of Abubakar (2017), Olijo (2017).

\section{Research Question Three}

What interpretation did the newspapers give to the activities of EFCC?

The researcher examined and analyzed the relationship between newspaper framing and its relative perception of the anti-graft crusade and activities of the EFCC in the Buhari-led democratic administration in Nigeria. They are discussed below:

The Daily Trust newspaper on $11^{\text {th }}$ January, 2016 published a report with the headline, Group condemns EFCC raid on Inde's residence. In the news discourse under review, the anti-graft agency was presented as victimizers and witch hunters. The text producer's use of the verb condemn assails the EFCC and their activities. Let us consider the excerpt below, as presented in the story, and its discursive practices.

Excerpt 1:

He said Nigerians would expect that the EFCC would have carried out its investigation and would have facts and not invade the residence of alleged suspect who has not been invited for any questioning...

From the discursive practice above, a text consumer can perceive the EFCC as despotic, they go about arresting perceived opposition members which is a flagrant neglect of the rule of law under the guise of fighting corruption. Their activities are more like unleashing the state apparatus against perceived opponents without due and proper investigation.

The Daily Sun newspaper on $24^{\text {th }}$ November, 2017 published a report, Patience Jonathan: Obey court order, NANS tells EFCC. Going by MAK Halliday's systemic functional grammar, every imperative mood begins with a lexical verb which is exactly what we have in this report. From the story, it is evident that NANS (National Association of Nigerian Students) is not taking the activities of the EFCC against patience Jonathan lightly; hence, they resort to the use of the imperative mood. The text producer however tried to pacify the situation by using the verb tell and called on (contained in the headline and the story); a subtle and diplomatic way of making a request. The writer uses these lexical verbs to report the news so as not to present the Students Union as being disrespectful; imagine if he had reported the news using either of these phrases NANS orders EFCC or NAN commands EFCC or NANS has ordered EFCC.

Excerpt 2:

What it tagged a noxious and brazen disregard of court ruling...

From the excerpt above, a proposition can be drawn that the Students' association wants the EFCC to stop any form of unwanted persecution of the former First Lady, this portrays EFCC as being too desperate at the detriment of the rule of law in order to prove to its benefactors that the EFCC is active and working. It is evident that the report above has a victimization framing.

The Punch newspaper on $31^{\text {st }}$ July, 2018 published a report, EFCC accuses Benue Governor of N22bn fraud. Perusal of the report indicated that the text producer is being evasive and bias with his report. This is evident in his choice of word "accuse": a situation where someone has done something morally wrong or illegal. The use of the lexical item "accused" in the Nigerian context is different from its usage in other parts of the world. A person who stands accused in the Nigerian context is one who is tried for a crime and he may thereafter be discharged and acquitted.

Excerpt 3:

The Economic and Financial Crimes Commission has linked Governor Samuel Ortom of Benue state to an alleged fraud to the tune of $\mathrm{N} 22 \mathrm{bn} .$.

The above excerpt illustrated another meticulous and diplomatic use of words by the text producer. The lexical item "linked": a connection between two people, things, or idea as used above is indicative that the person accused is being 
dragged into a mess he might not be guilty of, the word link is subtle and not outrightly accusing the Governor of being involved in the crime.

The Leadership newspaper on $24^{\text {th }}$ June, 2017 published a report, $40 \mathrm{~m}$ dollar contract: EFCC bid to inject fresh evidence stalls GEJ's cousin's trial. Here is the case of the prosecution of former President Goodluck Jonathan's cousin, Azibaola Robert, wife, and company in connection to a contract of 40 million dollars. From the news discourse above, we can deduce the framing of victimization. First, the way the news headline is presented is suggestive of the latter mentioned framing. The use of the expression "in a bid to inject fresh evidence "...is suggestive that the EFCC has an ulterior motive of witch-hunting and victimizing the accused. The use of the lexical verb inject connotes a preconception of inordinate ambition and viciousness. This definitely would appeal to the conscience of the text consumers who would tend to take sides with the defendants.

Let us consider these excerpts from the news:

Excerpt 4:

My lord, I am in a difficult situation again just as I was on Wednesday and I need your authorization to leave this matter and attend to another one in another court...

The request above was made by the prosecuting Counsel, SylvanusTahir. This result has confirmed those of Gever (2018), Gever et al. (2019) who found that the media usually have a negative interpretation of issues reported. This implies that the newspapers examined did not provide sufficient support to the Economic and Financial Crimes Commission. By extension, it also means that the media provided little to support the promotion of good governance.

\section{CONCLUSION}

Flowing from the findings of this study above, the following conclusions were made: This study has provided manifest frames used by newspapers in framing the activities of the Economic and Financial Crimes Commission under President Buhari as well as showing the prevalence rate of frames, most prominent frame and pattern of news frame in each of the selected newspapers. Secondly, on the premise of the findings of this study vis-a-vis Norman Fair clough's approach to Critical Discourse Analysis, it can be concluded that newspaper framing and presentation of the activities of the EFCC under the President Buhari is significantly influenced by the ideology of the text producers (newspaper Reporters/Editors) which manifests itself in their choice of linguistic items used in reporting. It is pertinent to state that this would affect the perception of the audience about the issue. The underlying fact behind this assertion is that the 21stcentury society is a post-modern society characterized by complex social structures and relations. Through high media dependency (a situation in which people rely heavily on newspaper reports for information about events and issues mostly beyond their personal contacts as well as their consumption of media information such as newspaper reports), people get influenced, not just by the information substance, but also by their manners of presentation encapsulated in how they are framed. This study has contributed to our understanding of how the media contribute to the promotion of good governance through the reportage of issues related to public financing. These results have implications on the reporting of financial crimes in a developing country by suggesting a strong need for newspapers to modify their approach and support government agencies in the fight against financial crimes.

\section{LIMITATION AND STUDY FORWARD}

This study did not examine the public perception of media framing of corruption issues. Further studies should look at this angle. Also, the researcher examined the media framing of anti-corruption efforts from just one administration. Further studies should compare more administrations in Nigeria for better understanding.

\section{ACKNOWLEDGEMENT}

We are thankful to all other researchers whose works were used in this study.

\section{AUTHORS CONTRIBUTION}

Ikusemiju Ayokunle Oluwadamilare wrote the draft while Dr. Anthony Ekwueme supervised and corrected it.

\section{REFERENCES}

1. Abdulbaqi, S. \&Ariemu, O. (2017), Newspapers framing of herdsmen-farmers' conflicts in Nigeria and its implication on peace-oriented journalism. The Creative Artists 11(2), 77-105.

2. About Nigerians (2018).List of Newspapers in Nigeria. Retrieved from www.aboutnigerians.com/list-andreview-of-newspaper-in-nigeria/

3. Abubakre, F. (2017). Press framing of anti-corruption war on Buhari's first year anniversary. Journal of Media Critiques (JMC), 3(12) 179-191. https://doi.org/10.17349/jmc117410

4. Adekola, O. \& Lamond, J. (2018). A media framing analysis of urban flooding in Nigeria: current narratives and implications for policy. Reg Environ Change, 18, 1145-1159. https://doi.org/10.1007/s10113-017-1253-y 
5. Adekunle, L. (2017). Newspaper framing of 2014 Ebola outbreak in Nigeria: assessing the nexus between audience perceptions and message influence. Retrieved from https://pdfs.semanticscholar.org/ fa22/81e880844b173ae565a0f75a9dddf08d6ad9.pdf

6. Ale, V. (2020). A library-based model for explaining information exchange on Coronavirus disease in Nigeria. Ianna Journal of Interdisciplinary Studies, 1,1-10.

7. Amenaghawon, F. (2017). Print media framing of the Niger Delta conflict in two selected Nigerian newspapers. An Appraisal of the Role of ICT as a Tool for Participatory Democracy in Nigeria, 1(1), 88-101.

8. Anyadike, D. (2015). Analysis of newspaper framing of the Nigerian Governor's Forum Election Crisis of 2013.Mediterranean Journal of Social $\quad$ Sciences, $6 \quad$ (6s1), https://doi.org/10.5901/mjss.2015.v6n6s1p315

9. Badiru, I. and Sunmonu, I. (2018).Reportage and framing of Pastoralist-farmer conflicts in Nigerian newspapers.Journal of Agricultural Extension, 22 (3), 1-8. https://doi.org/10.4314/jae.v22i3.1

10. Chime-Nganya, C., Ezegwu, D. and Ezeji Agnes (2017).Analysis of Nigerian newspapers framing of President MohammaduBuhari's medical leave to United Kingdom. Media and Communication Currents, 1(2), 39-56.

11. Chime-Nganya, C., Ezeji, A. and Ezegwu, D. (2017). Secessionist threat and media framing in Nigeria: Analysing IPOB/Nigeria Army clash/effects on the public. Renaissance University Journal of Management and Social Sciences (RUJMASS), 3(1), 2-20.

12. Egbunike, N. (2015). Framing the \#Occupy Nigeria Protests in newspapers and social media. Open Access Library Journal. 2(e1486), 1-13. https://doi.org/10.4236/oalib.1101486

13. Entman R. (1993.) Framing: Toward clarification of a fractured paradigm. Journal of Communication Studies.43, 51-58. https://doi.org/10.1111/j.1460-2466.1993.tb01304.x

14. Gever, V. C (2018). When Solution triggers more conflict: Frames and toner of media coverage of anti-open grazing law of Benue State, Nigeria. Media, War and Conflict. A SAGE Publication.

15. Gever, V. C,Okunu, M \&Oyeoku, E (2019). Media and opposing voices: News frames and slants of Nigeria's restructuring agitations. African Journalism Studies Taylor of Francis Publication. https://doi.org/10.1080/23743670.2018.1549576

16. Human Rights Watch (2011). Introduction: Corruption and Human Rights in Nigeria. Retrieved from https://www.hrw.org/report/2011/08/25/corruption-trial/record-nigerias-economic-and-financial-crimescommission.

17. Kari, K. (2020). Predictors of the utilization of digital library features among women patrons: The moderating role of marital status. Ianna Journal of Interdisciplinary Studies, 2,1-12..

18. Magu, I. (2018). EFCC recovers N871bn looted funds, 407 mansions in 3 years. Retrieved from https://www.vanguardngr.com/2018/11/efcc-recovers-n871bn-looted-funds-407-mansions-in-3-years-magu/).

19. Mailafia, O. (2017). On the Conceptualisation of Economic Crime (II). Retrieved from https://www.blueprint.ng/on-the-conceptualisation-of-economic-crime-ii/

20. McCombs, M. and Reynolds, A. (2002).News influence on our pictures of the world. Media effects: Advances in theory and research. Cambridge: Blackwell Pub.

21. McQuail, D. (2005). McQuail's Mass Communication Theory,(5th ed). Sage Publications Limited. https://doi.org/10.4135/9780857024374

22. Melugbo, D. Ogbuakane, M \& Jemisenia, J. (2020). Entrepreneurial potential self-assessment in times of COVID-19: Assessing readiness, involvement, motivation and limitations among young adults in Nigeria, Ianna Journal of Interdisciplinary Studies, 2, 1-14..

23. Ngwu, C., Ekwe, O. and Chiaha, C. (2015).Nigerian newspapers framing of the Chibok School Girls abduction (a study of Guardian, Daily Sun, The Trust and Leadership newspapers).Global Journal of Arts, Humanities and Social Sciences, 3(8), 78-93.

24. Nwabueze, C. and Edegoh, I. (2010).Framing the agenda: Press coverage of the 2008 teachers' strike in Nigeria. Journal of Communication and Media Research, 2(1), 113-120.

25. Nwabueze, C. and Ezebuenyi, E. (2019).Newspaper framing of Biafra Agitation under Buhari's administration and its influence on public support for the struggle. Retrieved from https://www.tandfonline.com/action/showCitFormats?doi=10.1080\%2F23743670.2019.1570296

26. Nwammuo, A., Nwafor, G. and Onuoama, E. (2019).Media trials and objectivity: Nigerian journalists' assessment of Sahara Reporters' framing of corruption allegations by Buhari administration. Retrieved from https://www.researchgate.net/publication /333616652

27. Obayi, P., Anorue, L.\&Onyebuchi, C. (2016). Demystifying content and data analyses in social science research. DeGreat Publishers.

28. Odii, A. Ngwu, O., Aniakor, C., Owelle, C., Aniagboso, C., Uzuanwu, W. (2020). Effect of COVID-19 lockdown on poor urban households in Nigeria: Where do we go from here? Ianna Journal of Interdisciplinary Studies, $1-12$.

29. Ogbonne, I. (2020). Cutting the head as cure for headache: Exploring the economic impact of Niger Delta Militancy on host communities. Ianna Journal of Interdisciplinary Studies, 1,1-16. 
30. Okoro, N. and Odoemelam, C. (2013). Print media framing of Boko Haram Insurgency in Nigeria: A Content Analytical study of the Guardian, Daily Sun, Vanguard and Thisday newspapers. International Institute for Science, Technology and Education, 3(11), 86-95.

31. Olijo, I. (2017). An Assessment of newspaper framing of anti-corruption war of President Muhammadu Buhari. Plasu Journal of Communication Studies, 1(1), 117-136.

32. Onifade, S. (2015).Media narratives on power relations in Nigeria: A Critical Discourse Analysis of three national newspaper columnists. Retrieved from http://i-rep.emu.edu.tr:8080/xmlui/handle/11129/1753

33. Onyebuchi, A. and Obayi, P. (2009).Analysis of newspaper framing of the 2009 rebranding Nigeria campaign. Retrieved from http://eprints.gouni.edu.ng/1030/1/ANALYSIS\%20 OF\%20NEWSPAPER\%20FRAMING $\% 20$ OF\%20THE\%202009\%20REBRANDING\%20NIGERIA\%20CAMPAIGNS\%20six.pdf

34. Pulse (2018).Pulse List 2018: Top 5 corruption stories in Nigeria. Retrieved from https://www.pulse.ng /news/loca 1/pulse-list-2018-top-5-corruption-stories-in-nigeria/5b98jm9

35. Salaudeen, K., Adebiyi, R. and Sanni, A. (2018).Framing of the anti-graft war in selected Nigerian Newspapers. NOVENA Journal of Communication, 6, 172-183.

36. Scheufele, D. (1999). Framing as a theory of media effects. Journal of Communication 49, $103-122$. https://doi.org/10.1111/j.1460-2466.1999.tb02784.x

37. Transparency International ranking of Nigeria (2018).Daily Trust, March, 5. Retrieved from https://www.dailytrust.com.ng/transparency-international-ranking-of-nigeria.html

38. Udende, P. and Chile, C. (2017). News Framing of Nigeria's Seventh National Assembly: Implication on perception and political actions of the publics. International Journal of Communication, 21(1), 146-156.

39. Ukonu, M.\&Ajaero, I. (2017). Newspaper framing of incumbent president and challenger in Nigeria's 2015 presidential election. Covenant Journal of Communication (CJOC). Vol. 8(2), 1-17.

40. Venturesafrica (n.d).Dasukigate:Here is a breakdown of the alleged misappropriation of \$2.1bn by dasuki and others. Retrieved from www.venturesafrica.com/dasukigate-here-is-a-breakdown-of-the-misappropriation-of-21-bn-meant-for-arms-deal-by-dasuki-and-others/

41. Waziri, F. (2011).The Economic and Financial Crimes Commission's (EFCC) critical role in growing the economy. Retrieved from https://www.proshareng.com/ news/Nigeria-Economy/The-Economic-and-FinancialCrimes-Commission's-(Efcc's)-Critical-Role-in-Growing-the-Economy-/14392

42. Wimmer, D. and Dominick, J. (2011).Mass media research: An introduction ( $9^{\text {th }}$ Ed.). Wadsworth. 